\title{
SOME NEW SAND-DWELLING COPEPODS
}

\author{
By A. G. Nicholls, Ph.D. \\ Marine Station, Millport
}

(Text-figs. I-7)

The copepods described in this paper come from two sources, the Firth of Clyde and the St Lawrence River. Several new species were collected from Balloch Bay on the Greater Cumbrae in 1935 and 1936 during an attempt to obtain some of the early species described from Scottish waters. The remainder were collected while working at the Biological Station at Trois Pistoles, Quebec, during a visit to Canada in 1937. The environment in Balloch Bay is composed of a fine muddy sand, strewn with boulders. The bay is on the eastern side of the island and therefore in a sheltered position. A description is given in Appendix III of The Biology of the Sea Shore, by Flattely \& Walton (I922). The conditions under which the Canadian material was found will be dealt with in a later paper describing the remainder of the collection from the St Lawrence; it will be sufficient here to state that the conditions are essentially marine.

Copepods from three allied genera are included here: Paramesochra T. Scott, I892; Leptopsyllus T. Scott, I894; and Remanea Klie, 1929. The first two have for some time been in a state of considerable confusion and it has been a matter of some doubt into which genus the various species should be placed. Several efforts have been made to clarify the position (notably by Klie, 1929 and Monard, 1935) but the more recent work of Kunz (1938) has produced a clear separation based on the presence or absence of an endopod on the second leg. When the variation in the structure of the endopods of the second, third and fourth legs is studied in these two genera it becomes apparent that such a separation is far from natural, but it will suffice until a thorough revision of these and allied genera has been made. In an earlier paper (1935) I suggested that the genus Emertonia of Wilson (1932) was in reality a synonym of Leptopsyllus. Kunz (1938) points out that it has enough distinct characters to render it a valid genus and with this opinion I must for the present agree.

Klie (1929) included Leptopsyllus and Paramesochra in a single genus and for this view there is much support since there is a considerable overlapping between the two. Moreover, Leptopsyllus littoralis $\mathrm{n}$.sp. is intermediate between Emertonia and Leptopsyllus, resembling the former in the possession of a I-segmented exopod in the first leg but differing from it in the absence of endopods on legs $2-4$.

Included in this paper are keys to the genera Paramesochra and Leptopsyllus 
based on those of Kunz, and extended to include the new species here described.

The following abbreviations have been used in the figures:
a.I. first antenna.
a.2. second antenna.
c.r. caudal rami.
g.a. genital area (ㅇ).
$U$. urosome.
$m d$. mandible.
$m x l$. maxillule.
$m x$. maxilla.
$m x p$. maxilliped.

I, II, III, IV, V, and VI. Legs I-6.

Genus Leptopsyllus T. Scott, I894

As stated above, this genus has now been modified and includes only those forms which lack endopods on the second legs.

\section{KeY to THE SPECIES}

$\begin{array}{llllllllll}\text { I. Third endopod absent } & \ldots & \ldots & \ldots & \ldots & \ldots & \ldots & \ldots & \ldots & 2\end{array}$ Third endopod present, I-segmented ... $\quad \ldots \quad \ldots \quad \ldots$ arcticus (Lang) I936

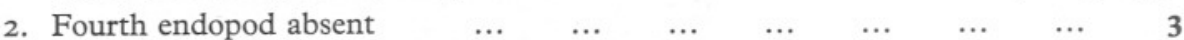

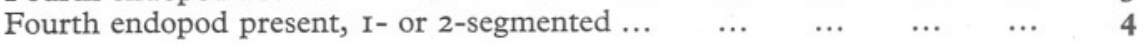

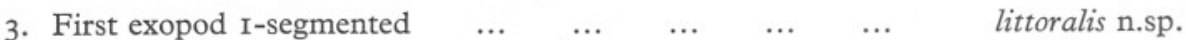

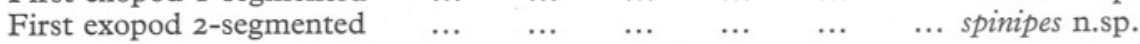

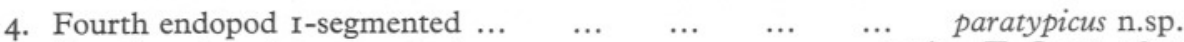
Fourth endopod 2 -segmented $\ldots \quad \ldots \quad \ldots \quad \ldots \quad \ldots \quad$ typicus $\mathrm{T}$. Scott, $\mathrm{I} 894$

Leptopsyllus littoralis n.sp. (Fig. I).

Occurrence. Balloch Bay, Firth of Clyde; washed from sand at about halftide level, at a depth of between 7 and $10 \mathrm{~cm}$.

Female. Length $0.48 \mathrm{~mm}$. Body tapering only slightly, somewhat constricted between segments. First antenna 9-segmented, the first two segments the largest; second antenna with the usual 3-segmented endopod and I-segmented exopod, the latter with two terminal and two lateral setae. Mouth parts of generic type. First leg with I-segmented exopod and 2-segmented endopod; exopod bearing four terminal and one lateral setae, with numerous small marginal setae; endopod with two large and one small setae at end of distal segment. Legs 2-4 all with 3-segmented exopods and no endopods. Fifth legs with distal segments fused with basal segment, the basal segments of opposite sides being fused in the mid-line and expanded into the usual lamella, which overlaps the genital area and is without setae; distal segments prolonged into spines and bearing four setae of which three are situated outside the spine. Caudal rami twice as long as wide and about two-thirds as long as anal segment. Egg-sac single with five or six spherical eggs carried one behind the other.

Male. Length $0.4 \mathrm{I}$ mm. First antenna 6-segmented; legs I-4 almost iden- 

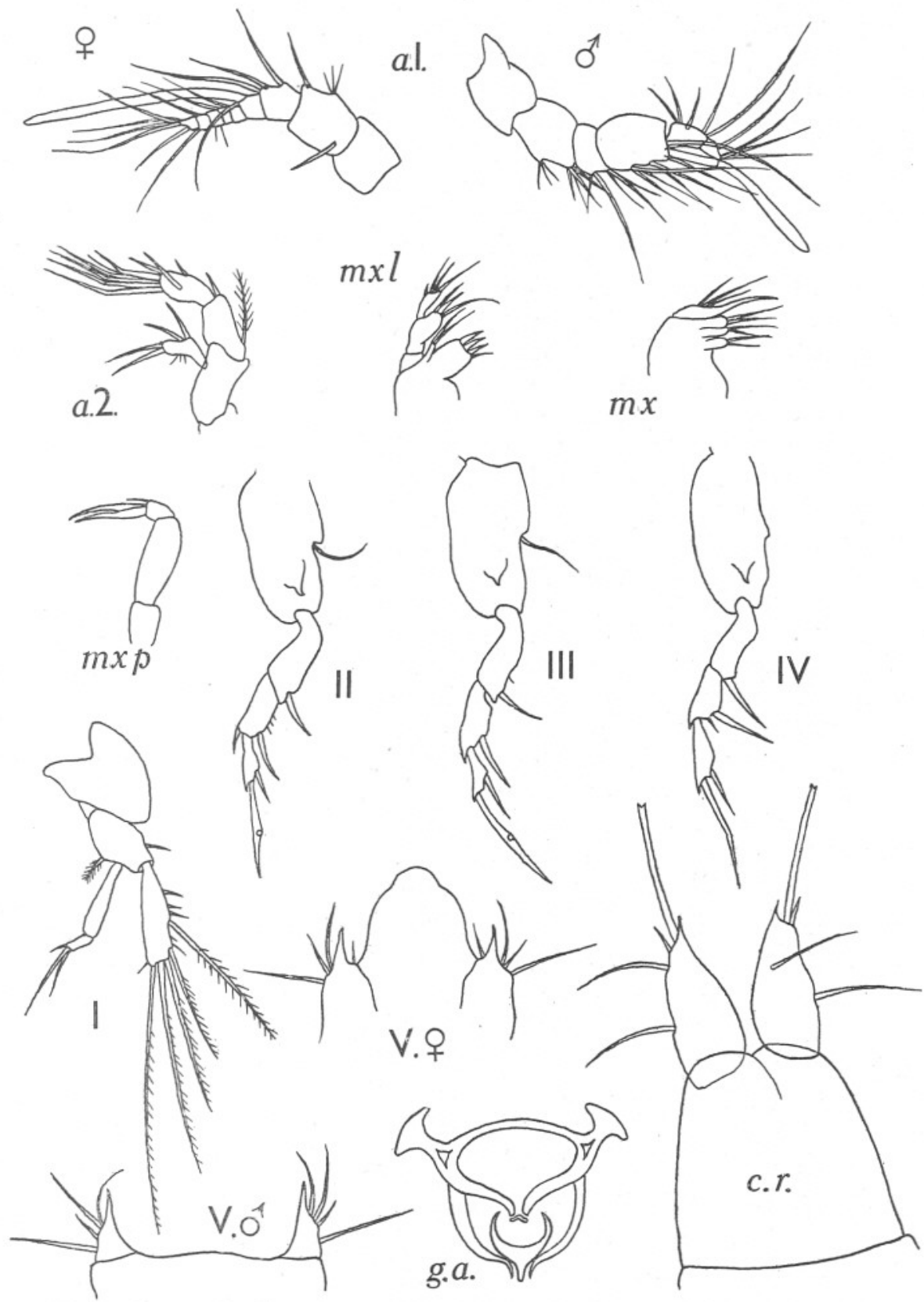

Fig. I. Leptopsyllus littoralis $\mathrm{n}$.sp. The figures are all drawn to the same scale. 
tical with those of the female; 5 th legs similar to those of female but without the large basal expansion.

This species resembles Emertonia gracilis Wilson (1932) in the structure of the first pair of legs, though the proportions of the segments of the endopod differ; it also differs from this and from previously described species of Leptopsyllus in lacking endopods on three pairs of legs, the second, third and fourth, and in the structure of the fifth legs.

\section{Leptopsyllus spinipes n.sp. (Fig. 2).}

Occurrence. Balloch Bay, Firth of Clyde; washed from sand near low-water springs, down to a depth of $10 \mathrm{~cm}$.

Female. Length $0.43 \mathrm{~mm}$. Body of usual form, moderately constricted between segments; urosome 4-segmented. Rostrum small; first antenna 7 -segmented, the basal segment the largest; second antenna with I-segmented exopod bearing two terminal and one lateral seta. Mouth parts of the usual structure. First legs with 2-segmented rami, endopod longer than exopod and tipped with two setae. Legs 2-4 with 3-segmented exopods and no endopods. Fifth legs of opposite sides fused in mid-line but basal segment not greatly expanded and ending in three pointed lobes; distal segments distinct, with two setae. Caudal rami as wide as long, subtriangular in shape, forming flattened plates armed with several short spines and setae.

Male. Length $0.36 \mathrm{~mm}$. Body similar to that of female; urosome 5-segmented. First antenna 7 -segmented, the 3 rd segment bearing a relatively large curved spine. Legs I-4 identical with those of female; fifth legs without inner basal expansion, distal segments with three setae; sixth legs with small basal expansion. Caudal rami somewhat longer than in female (half as long again as wide) and with fairly long terminal setae.

This species resembles $L$. littoralis in the absence of $2 \mathrm{nd}$, $3 \mathrm{rd}$ and 4 th endopods, but differs in the structure of Ist and 5th legs and caudal rami. The caudal rami of the male of this species are rather different from those of the female, which were probably slightly compressed while being drawn.

Leptopsyllus paratypicus n.sp. (Fig. 3).

Occurrence. Balloch Bay, Firth of Clyde; washed from sand.

Female. Unknown.

Male. Length $0.36 \mathrm{~mm}$. Body of usual form, with 5 -segmented urosome. First antenna 5 -segmented, bearing aesthetascs on $4^{\text {th }}$ and 5 th segments; 2nd antennae with I-segmented exopods bearing three terminal and one lateral seta. First legs with 2-segmented rami, the endopods slightly longer than the exopods. Second and third legs alike, with 3 -segmented exopods and no endopods. Fourth legs with 3-segmented exopods and I-segmented endopods, armed with a single large terminal spine. Fifth legs with basal segments of opposite sides fused in mid-line but not expanded; distal segments 

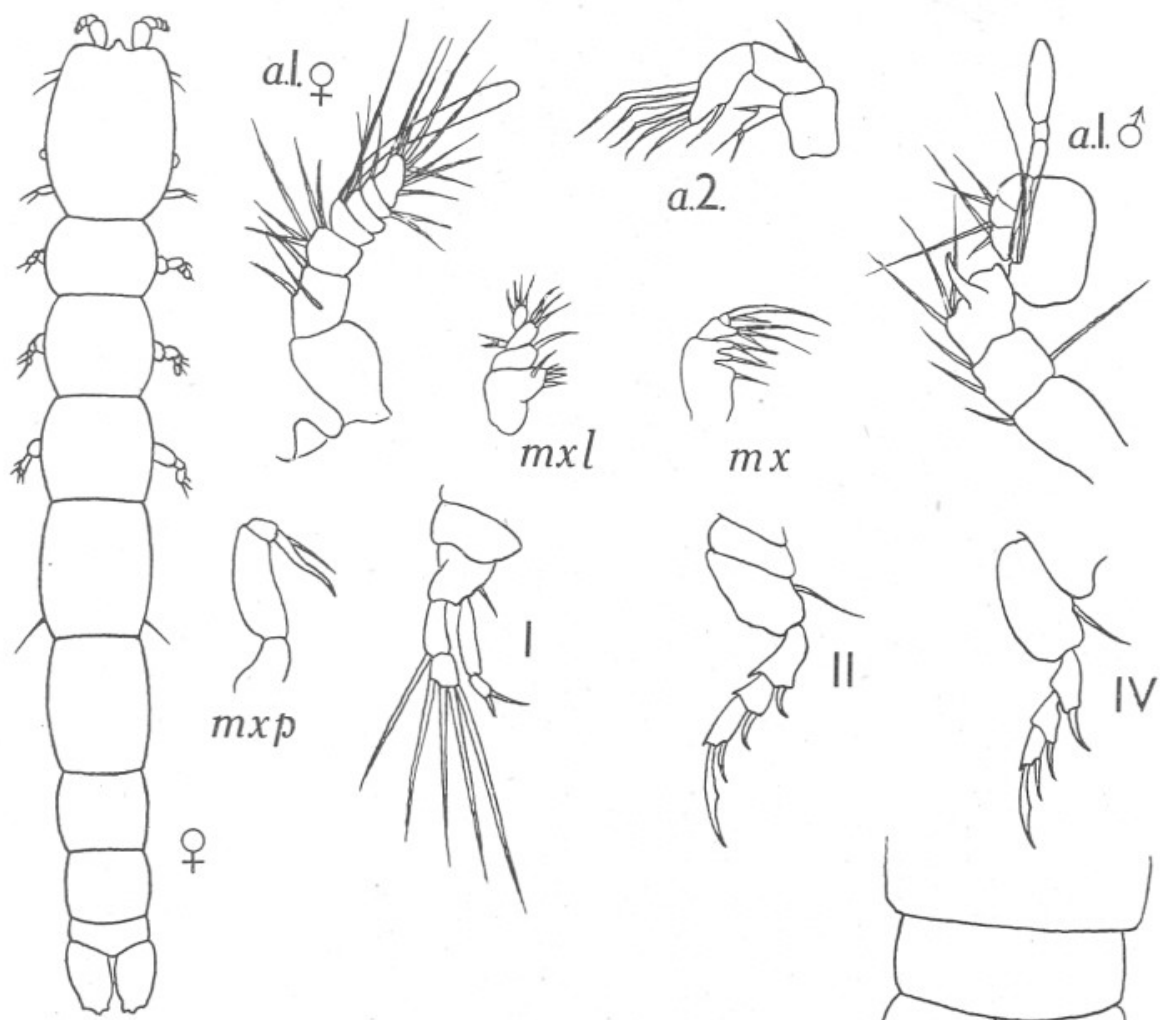

$m x$
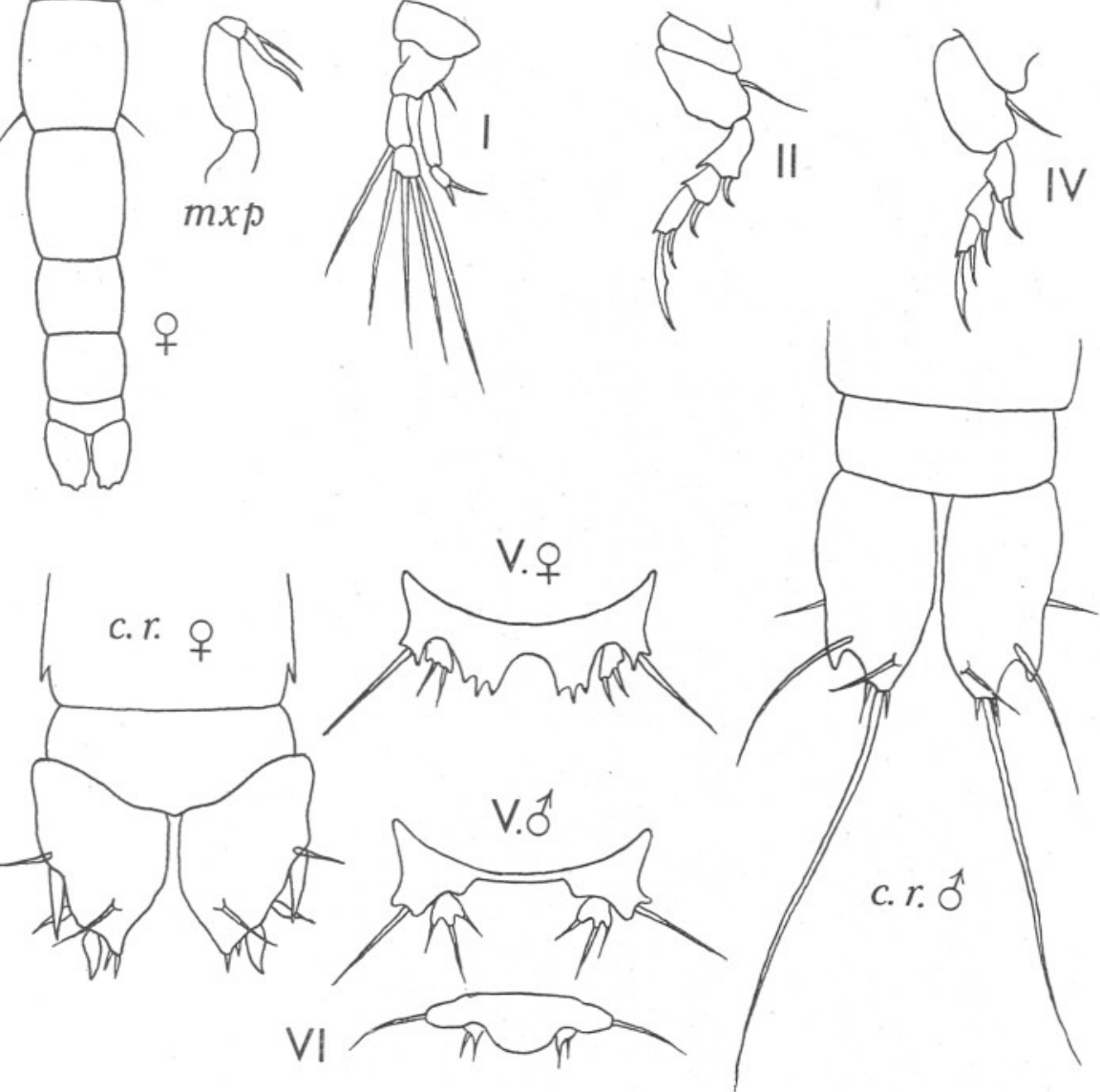

Fig. 2. Leptopsyllus spinipes n.sp. The figures are all drawn to the same scale except the dorsal view of the female which is less highly magnified. 


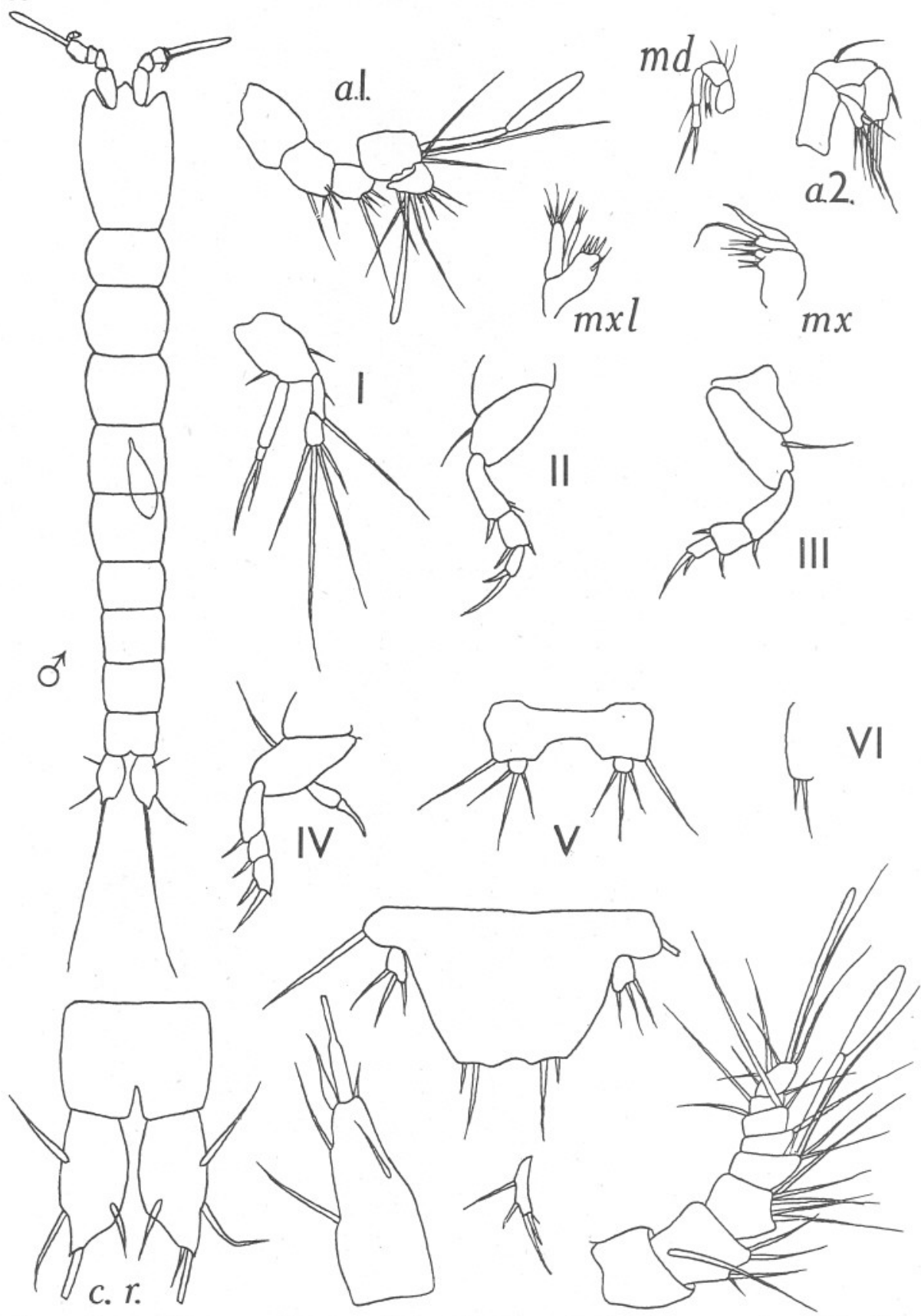

Fig. 3. Leptopsyllus paratypicus n.sp. Male only. The unlabelled figures are those of the first antenna, exopod of the second antenna, fifth legs, and caudal ramus of the female of Paramesochra minor (T. \& A. Scott). All to the same scale. 
with three long setae. Caudal rami twice as long as wide and a little longer than the anal segment, armed with one long and one short terminal seta and three other setae.

This species resembles $L$. typicus, of which only the female has been described, in having no endopods on the 2 nd and 3 rd legs but differs from it in having only I-segmented endopods on the 4 th legs and in the armature of the caudal rami. The great difference in size $(0.74$ and $0.36 \mathrm{~mm}$.) also rules out the possibility of this being the male of L. typicus.

\section{Genus Paramesochra T. Scott, I892}

Key to THe Species

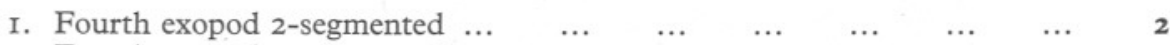
$\begin{array}{lllllllll}\text { Fourth exopod } 3 \text {-segmented } \ldots & \ldots & \ldots & \ldots & \ldots & \ldots & \ldots & 4\end{array}$

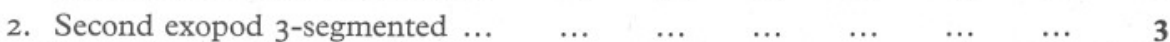
$\begin{array}{llllll}\text { Second exopod } 2 \text {-segmented } \ldots & \ldots & \ldots & \ldots & \ldots & \text { laurentica } \mathrm{n} . \mathrm{sp} .\end{array}$

3. Second endopod 2-segmented $\quad \ldots \quad \ldots$ intermedia (T. \& A. Scott) r895a $\begin{array}{lllllll}\text { Second endopod } \mathrm{I} \text {-segmented } & \ldots & \ldots & \ldots & \ldots & \ldots & \text { minuta } \mathrm{n} \text { n.sp. }\end{array}$

4. Basal segment of Ist antenna strongly hooked distally dubia $\mathrm{T}$. Scott, I892 $\begin{array}{lllllll}\text { Basal segment of Ist antenna not hooked } & \ldots & \ldots & \ldots & \ldots & \ldots & 5\end{array}$

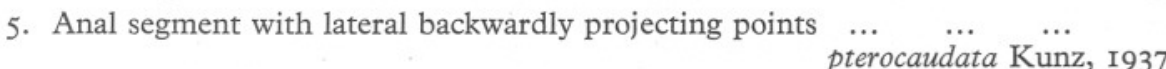

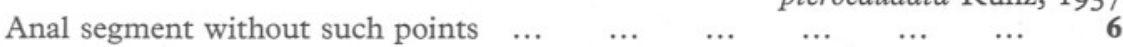

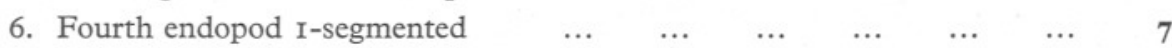
$\begin{array}{llllllll}\text { Fourth endopod } 2 \text {-segmented } & \ldots & \ldots & \ldots & \ldots & \ldots & \ldots & \text { II }\end{array}$

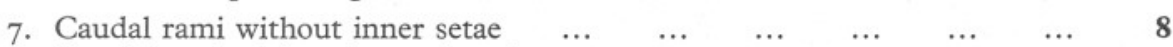
$\begin{array}{lllllll}\text { Caudal rami with an inner dorsal seta } & \ldots & \ldots & \ldots & \ldots & \ldots & 9\end{array}$

8. Caudal ramus with a stout spine at outer distal corner holsatica Klie, I929 Caudal ramus with plumose seta in place of spine ... $\quad . . \quad$ pygmaea $\mathrm{n}$.sp.

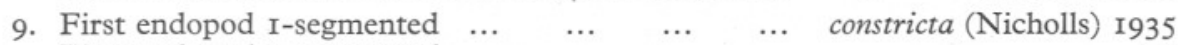
$\begin{array}{lllllllll}\text { First endopod } 2 \text {-segmented } & \ldots & \ldots & \ldots & \ldots & \ldots & \ldots & \ldots & \text { I0 }\end{array}$

Io. First endopod with large curved spine and one seta on terminal segment which is one-quarter of basal segment; size $0.40-0.46 \mathrm{~mm}$. ( $\AA^{+}$only) coelebs (Monard) 1935

First endopod with two spines on terminal segment which is one-third of basal segment; size $0.70 \mathrm{~mm}$. (o used for comparison) $\quad \ldots \quad \ldots \quad$ major $\mathrm{n} . \mathrm{sp}$.

II. Caudal ramus prolonged into a point posteriorly; end segment of 4th exopod with three setae; basal expansion of 5 th leg tapering to a point ... acutata Klie, I934

Caudal ramus not pointed posteriorly; end segment of 4th exopod with $\begin{array}{llll}\text { two setae; basal expansion of } 5 \text { th legs rounded, with two setae } & \ldots & \ldots & \text { I2 }\end{array}$

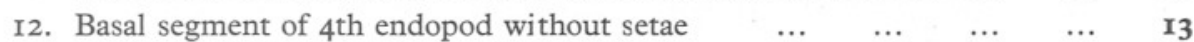
$\begin{array}{llllll}\text { Basal segment of } 4 \text { th endopod with an inner seta } & \ldots & \ldots & \ldots & \ldots & \mathbf{1 5}\end{array}$

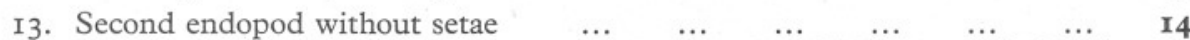
Second endopod tipped with one seta $\quad \ldots$ herdmani (Thompson \& Scott) 1900 
14. Caudal rami three times as long as wide; Ist exopod as long as whole endopod; size about $0.63 \mathrm{~mm}$. $\quad$... robertsoni (T. \& A. Scott) $1895 b$ Caudal rami $2-2 \frac{1}{2}$ times as long as wide; ist exopod no longer than basal endopod; size $0.33-0.46 \mathrm{~mm} . . . \quad \ldots \quad \ldots \quad$ minor (T. \& A. Scott) $1895 b$

I5. Basal segment of 3 rd endopod with one inner seta; end segments of 5 th legs rounded, bearing setae only $\begin{array}{lllllll} & \ldots & \ldots & \ldots & \ldots & \ldots & \text { similis } \mathrm{Kunz}, \mathrm{I} 937\end{array}$ Basal segment of 3 rd endopod without setae; end segment of 5 th leg tapering to end in a large spine $\quad \ldots \quad \ldots \quad \ldots \quad$ helgolandica Kunz, 1937

Paramesochra minor (T. \& A. Scott) I895b (see Fig. 3).

Occurrence. Trois Pistoles, St Lawrence River; washed from coarse sand near seaward end of breakwater, at a depth of between 5 and $8 \mathrm{~cm}$.

Distribution. Musselburgh, Firth of Forth; Kames Bay, Millport, Firth of Clyde; Kiel Bay, Germany.

A few specimens of this copepod were obtained near the breakwater at Trois Pistoles, Quebec, which differ in only small points from previous descriptions. The first antennae are 8-segmented in the female; the exopod of the 2nd antenna has three terminal and two lateral setae; the general proportions of the 5th legs are similar but the shape of the basal expansion is not quite the same; and the setae of the caudal rami do not quite correspond. These small differences do not justify a new species. It is remarkable that this species should be so widely distributed when it is customary among these sand-dwellers to find entirely different species in adjacent bays.

\section{Paramesochra pygmaea n.sp. (Fig. 4).}

Occurrence. Balloch Bay, Firth of Clyde; washed from sand near low-water springs, down to a depth of $\mathrm{IO} \mathrm{cm}$.

Female. Length $0.25 \mathrm{~mm}$. Body distinctly tapering posteriorly, somewhat constricted intersegmentally in the metasome; urosome 4-segmented. First antenna 7-segmented, basal segment the largest; 2nd antenna with I-segmented exopod armed with one terminal and two lateral setae. First legs with 2-segmented rami; endopod nearly half as long again as exopod; endopod with two terminal setae, exopod with four terminal setae. Second and third legs identical, with 3-segmented exopods and I-segmented endopods, the latter somewhat swollen distally and bearing each a single small terminal plumose seta; distal exopod segment bearing three spines and one plumose seta. Fourth legs similar to 2 nd and 3 rd but lacking the terminal plumose seta on the exopods. Basal expansions of 5 th legs large and almost completely fused in the mid-line, with two terminal setae on each side; distal segments with five setae. Caudal rami slightly more than twice as long as wide and about half as long again as anal segment, bearing three unequal setae terminally and one lateral seta.

Male. Length $0.24 \mathrm{~mm}$. Body similar to that of the female but with 5-segmented urosome. First antenna 5-segmented, with a short stout 
aesthetasc on the $4^{\text {th }}$ segment. Legs I-4 identical with those of female; 5 th legs with basal expansion scarcely extending beyond end of distal segments

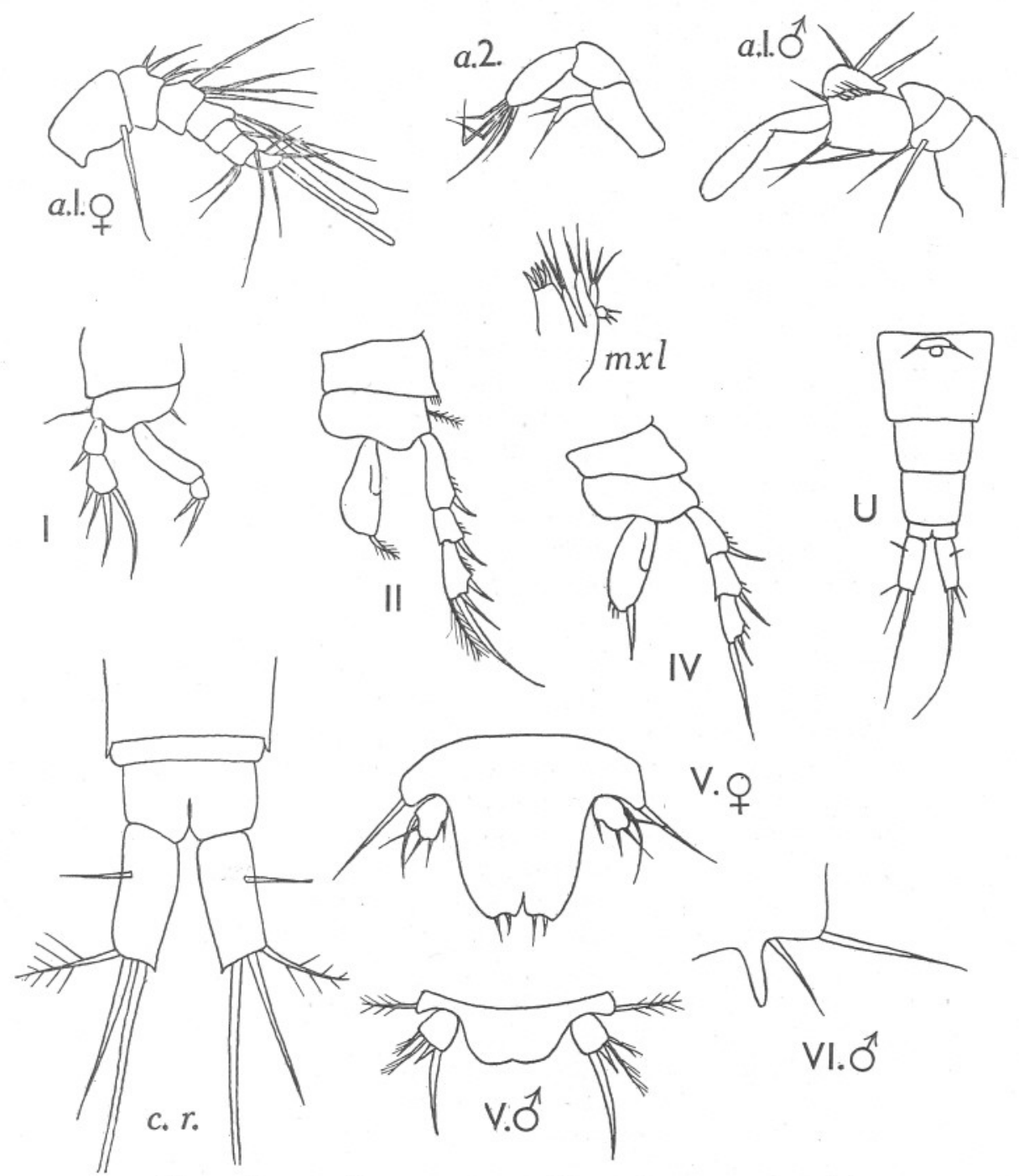

Fig. 4. Paramesochra pygmaea n.sp. Except for the urosome of the female the drawings are all to the same scale.

and without terminal setae; distal segment with one long spine and three short setae.

This species resembles $P$. holsatica in the general structure of its legs and in its small size, but can be distinguished easily by the presence of a small 
plumose seta at the outer corner of the caudal ramus in place of the stout spine in holsatica.

Paramesochra minuta n.sp. (Fig. 5).

Occurrence. Balloch Bay, Firth of Clyde; washed from sand.

Female. Length $0.38 \mathrm{~mm}$. Body not tapering very much; urosome 4-segmented, anal segment very short. First antenna 8-segmented; exopod of 2nd antenna I-segmented with two terminal and one lateral seta. First legs with 2-segmented rami about equal in length or the exopod slightly the longer. Legs 2 and 3 with 3 -segmented exopods and I-segmented endopods, the latter somewhat narrowed distally and bearing only three short hairs. Fourth legs with 2-segmented exopods and I-segmented endopods, not constricted terminally but bearing a single large spine. Fifth legs with very large basal expansions entirely fused and semi-circular in outline, with one seta on each side; distal segments very small and fused with basal segments, distinguishable only as small knobs each bearing two setae. Caudal rami twice as long as wide and about half as long again as the anal segment.

Male. Unknown.

This species resembles $P$. intermedia in several particulars but differs in size, in the structure of the 2nd endopods and of the 5th legs.

Paramesochra major n.sp. (Fig. 6).

Occurrence. Baie de Mille Vaches, St Lawrence River; washed from very coarse sand taken by grab in a depth of $8 \mathrm{~m}$.; numerous specimens.

Female. Length $0.80 \mathrm{~mm}$. Body with metasome wider than urosome, tapering gradually posteriorly; urosome 4 -segmented. First antenna 9-segmented, basal segment the largest. Second antenna with I-segmented exopod bearing one terminal and two lateral setae and two small hairs. First legs with 2 -segmented rami, the endopod about twice as long as the exopod and with its distal segment not always clearly separated from the basal segment, the latter about five times as long as the end segment. Legs 2-4 with 3-segmented exopods and I-segmented endopods. The distal segment of the 2nd exopod with three spines and one plumose seta, of 3 rd exopod with two spines and one plumose seta (the proximal spine being absent) and of 4 th exopod with two spines only. Second and third endopods rounded, with one terminal plumose seta; 4 th endopod tapering, with one stout spine. Fifth legs with basal expansions fused for two-thirds of their length, bearing two setae; distal segments small, with three setae. Caudal rami three times as long as wide and twice as long as anal segment. Egg-sac single, with 9-Io eggs.

Male. Length $0.70 \mathrm{~mm}$. Body similar to that of female; urosome 5-segmented. First antenna 6-segmented with a short stout aesthetasc on 4th segment. First leg as in female but with basal endopod segment only three times as long as distal segment. Second and third legs similar and like 2nd leg 


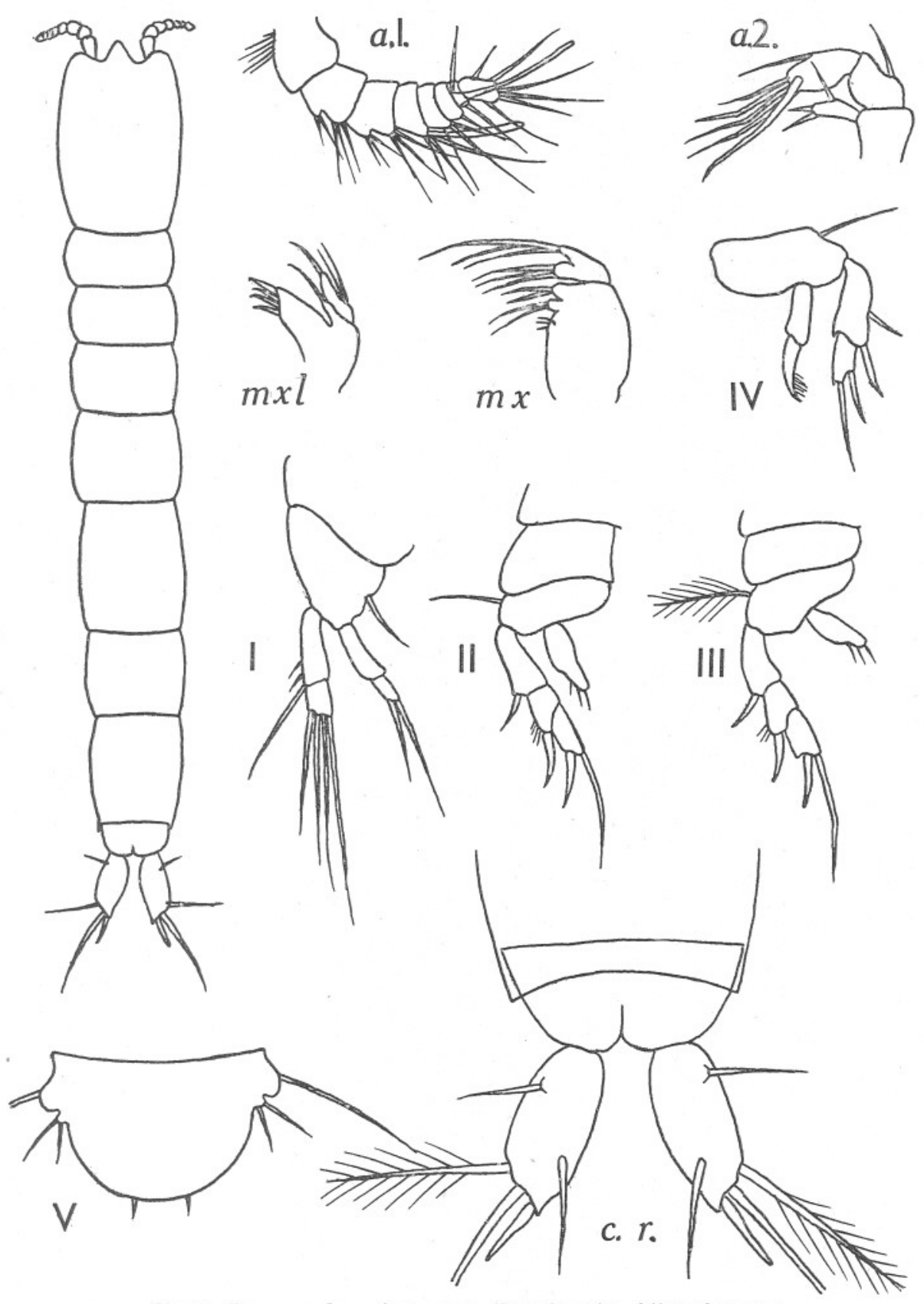

Fig. 5. Paramesochra minuta n.sp. Female only. All to the same scale except for the dorsal view of the adult. 
A. G. NICHOLLS

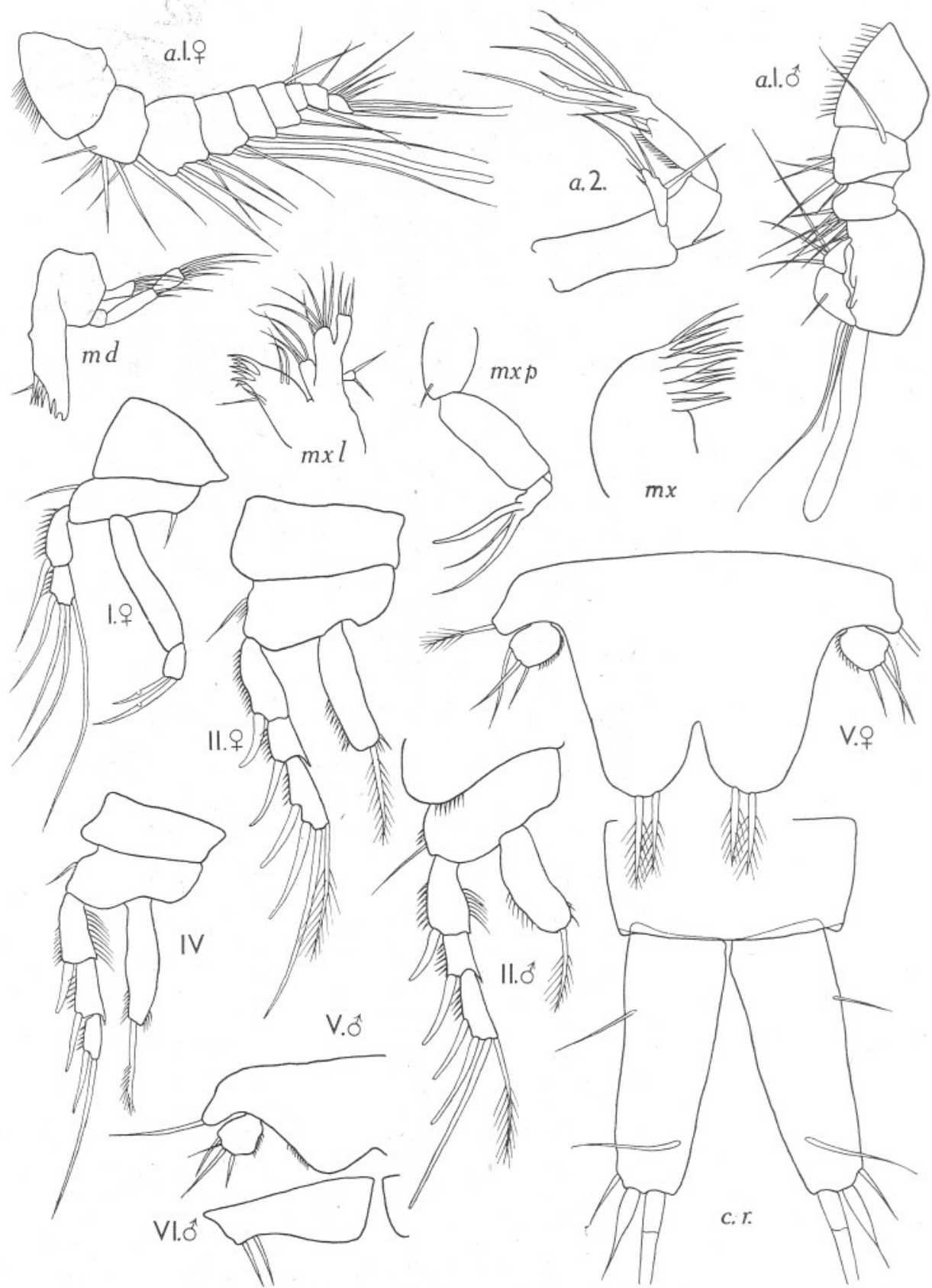

Fig. 6. Paramesochra major n.sp. All figures drawn to the same scale. 
of female. Fourth legs like those of female. Fifth legs with small basal expansion, without setae; distal segment with four setae. Caudal rami like those of female.

This species is the largest yet described belonging to this genus, though Leptopsyllus typicus is nearly as large, and although resembling Paramesochra coelebs (only the male of which is known) is quite easily separated by the difference in the Ist legs and in the size.

Paramesochra laurentica n.sp. (Fig. 7).

Occurrence. Baie de Mille Vaches, St Lawrence River; washed from coarse sand taken by grab from $8 \mathrm{~m}$. One specimen only.

Female. Length not known. First antenna 7 -segmented, the 3 rd the largest. Second antenna apparently without an exopod but this may have been lost in dissection. First leg with 2-segmented rami, endopod nearly twice as long as exopod. Legs 2-4 with 2-segmented exopods and I-segmented endopods, the latter with a single seta in 2nd and 3 rd legs and with a single stout spine in $4^{\text {th }}$ legs. Distal segments of 2 nd and 3 rd exopods each with four spines and one plumose seta; 4 th exopod with two spines and one plumose seta. Fifth legs of the usual pattern, basal expansion with two setae on each side; distal segment with three setae. Caudal rami little more than twice as long as wide, with three unequal setae.

Male. Unknown.

This species differs from all other species so far described in the presence of 2 -segmented exopods in legs I-4.

\section{Genus Remanea Klie, 1929}

This genus was described by Klie to receive a new copepod obtained in Kiel Bay. While it differs from Paramesochra and Leptopsyllus in the presence of a 3-segmented Ist exopod and the 2-segmented exopod of the 2nd antenna, it resembles many species of Paramesochra in its shape and in the 5th legs which are fused for part of their length. It appears to me to be a related genus.

\section{Remanea arenicola Klie, 1929.}

Occurrence. Fintry Bay, Isle of Cumbrae, Firth of Clyde; washed from fairly coarse sand near low-water mark.

Distribution. Kiel Bay, in coarse sand.

Several specimens of this copepod were taken in 1935 from the relatively coarse sand of Fintry Bay on the west shore of the Cumbrae, exposed to rough weather. These specimens are very slightly larger than those found by Klie (female $0.38 \mathrm{~mm}$.), but that is the only difference. 
A. G. NICHOLLS

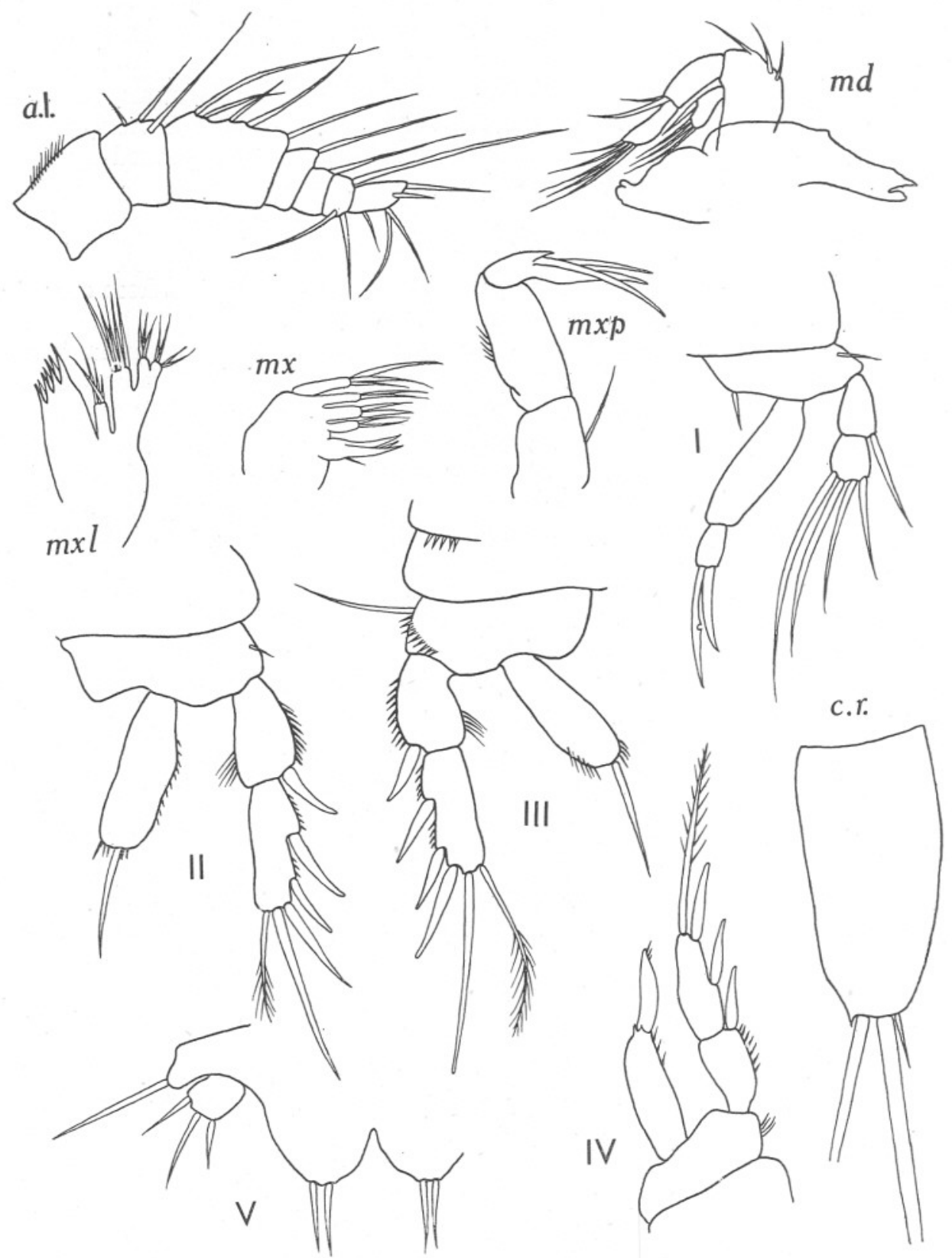

Fig. 7. Paramesochra laurentica n.sp. Female only. All figures drawn to the same scale. 


\section{REFERENCES}

KLIE, W., I929. Die Copepoda Harpacticoida der südlichen und westlichen Ostsee mit besonderer Berücksichtigung der Sandfauna der Kieler Bucht. Zool. Fahrb., Bd. 57 , pp. 329-86.

— I934. Die Harpacticoiden des Küstengrundwassers bei Schilksee (Kieler Förde). Schr. Naturwiss. Ver. Schleswig-Holstein, Bd. xx, pp. 409-2I.

Kunz, H., I937. Neue Harpacticoiden (Crustacea Copepoda) von Helgoland. Kieler Meeresf., Bd. I, pp. 352-8.

I938. Die Sandbewohnenden Copepoden von Helgoland. I. Kieler Meeresf., Bd. II, pp. 223-54.

LANG, K., I936. Die während der Schwedischen Expedition nach Spitzbergen I898 und nach Grönland 1899 eingesammelten Harpacticiden. Kungl. Svenska Vetensk. Handl., 3rd ser., Vol. xv, No. 4, pp. I-55.

Monard, A., I935. Étude sur la faune des Harpacticoïdes marins de Roscoff. Trav. Stat. Biol. Roscoff, Fasc. I3, pp. I-90.

Nicholls, A. G., I935. Copepods from the interstitial fauna of a sandy beach. Fourn. Mar. Biol. Assoc., Vol. xx, pp. 379-406.

ScotT, T., I892. Additions to the fauna of the Firth of Forth. IV. Ioth Ann. Rep. Fish. Bd. Scot., Pt. III, pp. 244-72.

I894. Additions to the fauna of the Firth of Forth. VI. I2th Ann. Rep. Fish. $B d$. Scot., Pt. III, pp. 23I-7I.

ScotT, T. \& ScotT, A., I895a. On some new and rare Crustacea from Scotland. Ann. Mag. Nat. Hist., Ser. 6, Vol. xv, pp. 50-9.

I895 b. On some new and rare species of Copepoda from Scotland. Ann. Scot. Nat. Hist., pp. 28-35.

Thompson, I. C. \& ScotT, A., I900. Some recent additions to the Copepoda of Liverpool Bay. Trans. L'pool. Biol. Soc., Vol. xIv, pp. 139-44.

Wilson, C. B., I932. The copepods of the Woods Hole region, Massachusetts. U.S. Nat. Mus., Bull. 158. 